\title{
Aspects to Reform College English Teaching under the Background of Socialization of NMET
}

\author{
Junling Yan \\ School of Foreign Languages, Chifeng University, Chifeng, Inner Mongolia, China
}

13947659118@126.com

\section{Keywords: Socialization of NMET; Reform college english teaching; Aspects}

\begin{abstract}
As is known to all, English is an important subject of our learning, but as the socialization of the college entrance examination English reform, English major is faced with the problems of the reform. Different people have different views. Some people think that English learning and examination is essential and English is an important tool of communication for us to go to the world. We should pay more attention to speaking and listening. Some think people must learn English well because of dealing with the university entrance exam no matter how to reform English which is not back out of the college entrance examination. However, some people think that most students spend more time on learning English than learning the mother tongue. No matter how much people say, English as an important tool of communication, it is necessary for us to understand foreign culture. We should learn and know English with peace of mind. Under the background of socialization of NMET, constant reform in college English teaching can adapt to the development of talents and the needs of the society.
\end{abstract}

\section{Introduction}

As is known to all, English is an important subject of our learning, but as the socialization of the college entrance examination English reform, English major is faced with the problems of the reform. Different people have different views [1]. Some people think that English learning and examination is essential and English is an important tool of communication for us to go to the world. We should pay more attention to speaking and listening. Some think people must learn English well because of dealing with the university entrance exam no matter how to reform English which is not back out of the college entrance examination. However, some people think that most students spend more time on learning English than learning the mother tongue [2]. No matter how much people say, English as an important tool of communication, it is necessary for us to understand foreign culture. We should learn and know English with peace of mind. Under the background of socialization of NMET, constant reform in college English teaching can adapt to the development of talents and the needs of the society [3]. Under the background of socialization of NMET, our college English majors respond to the call in order to conform to the trend of the times and advance with the times. We should be conducted in the following aspects to explore the teaching reform [4].

\section{College English Training Goals}

Now we are in a knowledge economy era and the competition between countries is the talent competition, so it is of a country's top priority to cultivate innovative talents and it is the key to improve a country's overall competitiveness. Cultivating innovative talents in college English teaching reform and establishing a new talent education system are necessary. Cultivate students' practice ability, innovation spirit, independent thinking ability and creative ability. On the basis of learning English we can open trade, news and so on as a compound professional in order to adapt to the social demand for applied talents, but we also need theory and general talents. Besides, we should cultivate more creative talents. The classification standards of different types of talents are different, but they are connected with each other. No matter what kind of talents, they should be innovative so as to integrate into society. In connection with language, culture and thought, students use the English language consciously. They don't just study knowledge which are taught in 
textbooks. On the one hand, they can apply it. On the other hand, they must achieve mastery through a comprehensive study.

\section{College English Professional Curriculums}

English professional courses are divided into professional skill courses, English professional knowledge courses and related professional knowledge courses. Generally take English as the language of instruction. Society now needs a new type of English talents who must have solid English foundation and rich knowledge, and can use English skillfully in foreign affairs, education, economy, trade, culture, science and technology, military and other departments engaging in translation, teaching, management, research and other work. Therefore, to break the traditional curriculum mode is imminent [5].

In English teaching, don't only rely on extensive reading course or integrated English course. In order to keep up with the need of the times, join some other professional courses or a minor in other professional courses to enrich students' thinking ability and to improve students' eyesight. We can take Tsinghua University for example. English professional courses include language, literature and culture, including compulsory courses and optional courses. English major curriculums are as follows:

\section{Language}

An Introduction to Linguistics

The Structure of English Grammar

English Lexicology

Applied Linguistics

English Phonetics Tests

\section{Literature}

English Literature

American Literature

European and American Short Stories

Modern European Literature

Film Appreciation Literature

\section{Culture}

Introduction to Western Culture

Language and Culture

Literature and Society

Culture and Translation Criticism

Religious Thoughts in the West

From the top, you can see that English courses have completely met the needs of society. If universities are trying to reform, believe that students learn professional knowledge, have effective training to develop their various abilities and improve their comprehensive level. At the same time they become society talents.

\section{College English Test Methods}

Tests are a key link of checking the quality of teaching and the grasp of students' knowledge. At the same time, tests guide teaching. A test has three principles: credibility, that is, it is able to timely and accurately reflect students' learning level; effectiveness, that is, it can effectively test students' knowledge level at some stage and it can make the results reflect the desired effect; development, that is, consistent with students' actual situation, it can let them find their deficiencies, dig out their own potential and continue to learn after doing. Tests, of course, can reflect students' basic skills, namely, vocabulary, grammar, syntax, translation, understanding and ability to solve practical problems and so on [6].

With the development of the society, the traditional test patterns don't work and they need reforming. On the basis of the original, inject new methods. On the basis of following timeliness, 
scientificity and openness, they need reforming. We can put points into several parts. Besides traditional paper-based tests, add extracurricular reading in the usual teaching, namely direct reading material or stimulate students independently to find the answers. For example, you can give a story - What Happened to Manners? Let students read it carefully. Then ask questions about the article. What could a gracious manner probably bring about according to the author? You can also ask questions related to the meaning of the sentence in your own language, for example, I bet the note my guest sent me did not take long to write. You can also ask synonyms or antonyms of words, for example, the synonym of the word. Don't use this advanced vocabulary generally. People are accustomed to using the word thankful. Through tests, students remember such advanced vocabulary and improve their ability. In this way it can not only increase reading quantity but also arouse students' learning enthusiasm. Add spoken tests because the spoken language itself has a wealth of interpersonal communication and era characteristics. Now society is a severe lack of oral talents with the high quality. If we continue to improve students' oral English ability, it can not only improve their own ability but also meet the needs of society. Specifically, we should can fully test students' ability of expression and contents of knowledge. Modern spoken language teaching connects tests and practical application; Of course it also accords with the standard of college students' English course examination. Society need have good oral English talents. We must make students in specific or more casual situations have their own thinking and speaking ability. English professional test methods need reforming constantly with the development of the times so as to cultivate more excellent English talents.

\section{College English Textbook Compilation}

College English textbook compilation reflects characteristics of different times, the development trend of society, the development trend of teaching method and the development of education undertakings. Therefore, it is very important for students' development to writing textbooks. Writing teaching materials not only pay attention to listening, speaking, reading and writing but also pay attention to cultivating students' various abilities, such as language expression ability, thinking ability, innovation ability and so on. The ultimate goal is to enable students to use English well to express and deal with things, to communicate independently and to meet the needs of work.

We can encourage and promote university teachers and students according to the actual situation of the university to work out corresponding teaching materials. It is particularly important to pay special attention to quality. Consult relevant experts and scholars or unite universities to develop distinctive teaching materials, for example spoken language teaching materials. According to local characteristics, local conditions and customs, contact the social development. Include places of interest, delicious food and the development of this place and so on. Let students feel cordial while learning. Contact actual professional terms, write different careers and combine theory with practice. Give materials relevant video CDs and online editions [7].

To sum up, the writing of the textbook should reflect "to teach fishing is better than teach them to fish". Students study textbook knowledge and use it in actual life and work. It is long-term reform work to train students' ability of handling things [8].

\section{College English Teachers' Development}

A teacher is key and guarantee of education development. Its quality development and construction growth of its team are quite critical. Because talent markets require a lot of English professional talents with high quality, college English teachers' requirements are becoming higher and higher [9].

Teachers not only teach students professional knowledge and firstly they let students have mental health. Notice students' movements, find problems in time and timely correct them. Help students to set up the correct world outlook, the outlook on life and values so as to cope with all sorts of things in a positive way[10]. I feel humor is particularly important and a teacher learns how to have this quality! A teacher must constantly use appropriate humorous language in time in teaching. A 
teacher must make boring knowledge class become more active, make abstract things more visual and make theoretical things more specific. Teachers also should constantly change teaching ideas and innovation. Ethics is a special important thing. It relates to the direction and development of the whole education career. Teachers must stimulate students' learning fun, make them build self-confidence, develop good study habits and learning methods through certain practice. Cultivate their ability of autonomous learning and cooperative spirit.

That is to say, changing education career to a certain extent is to change a teacher. A teacher is a beacon and broker, so teachers should follow the development of the times, constantly update and provide new blood for the development of society.

\section{Conclusion}

With informationization and economic globalization of human lives, strengthen exchange and cooperation among people in different languages, which makes English as a language even more important. English is the world common language and is playing an increasingly important role in people's lives. We, as the biggest developing country in the world, English is essential. Under the background of socialization of NMET, constant reform in college English teaching can adapt to the development of talents and the needs of the society. Its reform includes training goals, professional curriculums, test methods, textbook compilation and teachers' development. At the same time, we reform thinking, teaching methods and innovation thinking [11]. We believe English will be shown in different styles to us. Teachers must educate flowers of the motherland with different teaching methods. Let students become the owners of the new period. Teaching reform makes us have a new level of understanding and learn many new things. Meanwhile, let students have their different opinions. Teachers will make classrooms become full of more vigor and vitality. During this period, teachers and students progress together. Teaching others teaches yourself.

In short, the purpose of English teaching is to serve students. Let students constantly enrich themselves and cultivate national pillars. Its final purpose is to serve society and meet the needs of society.

\section{References}

[1] Zheng Caiyun and Chen Shugen. Socialization of the College Entrance Examination Question Analysis [J]. Journal of Beijing Industrial Vocational and Technical College, (2009)(7) : $143-146$

[2] Li Chengwei. Pros and Cons about NMET Socialization [J]. Journal of Exam Weekly, (2014) (10) : 4

[3] Li Tao. The Socialization of the College Entrance Examination Study [J]. Modern Education Science, (2013)(2) : 5-10

[4] Han Huiqing.College English Teaching Reform Ideas [J]. Journal of Luoyang Normal College, (2003) (3) : 113-115

[5] He Qixin, Yin Tongsheng, etc. Several Opinions on Reform of the Foreign Language Professional Undergraduate Course Education [J]. Foreign Language Teaching and Research, (1999) (1) : 24-28

[6] Cheng Xiaotang. Examination is not the natural enemies of the new curriculum - on the new curriculum under the background of the relationship between teaching and evaluation thinking [J]. People's Education,( 2007).

[7] Jia Guodong. Multimedia Teaching to Promote New Ways of College English Teaching [J]. Foreign Language World, (1999)(2) : 30-35

[8] Ministry of Education. English Course Teaching [M]. Shanghai Foreign Language Education Press,(2007).

[9] Ministry of Education. Teaching Requirements for College English Courses [M]. Shanghai Foreign Language Education Press,(2007).

[10] Yan Ming. The Research on the Teaching Theory and Practice of ESP [M]. Heilongjiang 
University Press, (2008).

[11]Dai Weidong and Huang Ren.Changing Ideas, Comprehensively Promote the Reform of Foreign Language Teaching [J]. Journal of International Studies, (1997)(6) : 1-4 